\title{
Public Awareness, Not Public Relations
}

\author{
B ER N A D D I XON
}

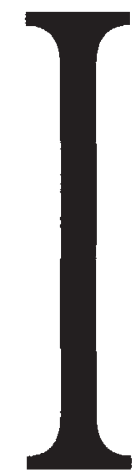

$\mathrm{t}$ was a daring experiment, but it worked: $\mathrm{A}$ major scientific congress, with the doors open to the public and several contentious issues on the agenda. Some extremely cogent debate, plus widespread coverage in the media. Timorous souls who felt either (1) that the public would not come, or (2) that the public would come but would rant and riot, were pleasantly reassured. The organizers were delighted. Could this become a piece of history, a model for wider access to similar meetings in the future?

The experiment took place at the 17 th International Congress of Genetics, held recently in Birmingham, U.K., and attended by some 3000 geneticists from around the world. Returning to Britain for the first time since 1939, when the Congress was affected by the Lysenko affair in the Soviet Union and the outbreak of World War II (Bio/Technology 11:646), the occasion was already redolent with history. Now, with an extra dimension added to what would otherwise have been simply a routine exchange of research findings between human, animal, plant, and microbial geneticists, there is the prospect that other scientific bodies will be encouraged to involve the public in their deliberations in a similar way.

Plant breeder Dick Flavell, director of the John Innes Institute in Norwich, first suggested the need for the Birgmingham innovation. Supported by Congress president Sir Ralph Riley, the idea became flesh as a public awareness program under the leadership of Simon Baumberg, a microbial geneticist at the University of Leeds. It consisted of presentations and discussions on four evenings of the week, plus four sessions occupying virtually the whole of the closing day. Congress participants took part, as did members of the public, who also received free copies of a booklet reviewing current trends in genetics and genetic engineering.

Two features were particularly impressive. The first was the high level of public interest in the whole range of subjects on offer. Genetic fingerprinting and gene therapy ("How far can geneticists morally go, and are we equipped to deal with the consequences?") attracted audiences of $400+$. But so too did sessions on topics such as the need to maintain biodiversity and the development of new crops to meet the problems of hunger, malnutrition, and population growth.

There was, in addition, appreciative recognition that "public awareness," here at least, had not been inter- preted simply as public appreciation. This was not a public relations exercise to sell the wonders of science to the masses, but an effort to share doubts, ventilate emerging dilemmas, and confront head-on even some of the more extreme scenarios, which the hard hats of science tend to dismiss impatiently as beyond serious consideration.

Thus one of the evening discussions was devoted to the lessons of genetics in Nazi Germany. It was introduced by Benno Müller-Hill, professor of genetics at the University of Cologne and author of Murderous Science - the Elimination by Scientific Selection of Jews, Gypsies, and Others, Germany 1933 1945 (Oxford University Press, Oxford). MüllerHill's anxieties received conspicuous support from Ralph Riley in his presidential address. "The racist Nazis with their appalling genocide, and some of their contemporary successors, the ethnic cleansers, have chosen to believe that genetics is all-important in producing the ideal man and ideal society. This led in the past to some truly horrifying pseudo-genetical experimentation of which we all must feel ashamed," he said. "Few of us will doubt the validity and value of individual and family choice in the direction of negative eugenics. Nevertheless, we must always be on our guard against the emergence of public policies with eugenic components, especially in positive eugenics, not only because of the infringements of human rights that will inevitably occur but also because of the unknown consequences for society that would result."

There were valuable cautions, too, regarding genetic screening and whether the practice of identifying individuals predisposed to particular conditions is always the unmitigated benefit that its most enthusiastic promoters would have us believe. Max Perutz, in his opening address, contrasted the undoubted rewards of thalassemia screening with the more much

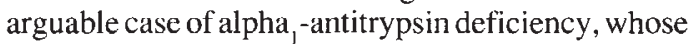
victims are especially likely to develop emphysema if they smoke. For that reason, a screening project was initiated in Sweden some years ago in which young people at risk were identified and their parents were urged to persuade the children not to smoke. But the results of this well-intentioned project were not as intended. There was increased aggravation between the generations, psychological distress and higher levels of smoking.

What better example to emphasize that the robust and well-intentioned application of science to human welfare can still go seriously astray? 